\title{
LE'TTER FROM LIEUTENANT CLARKE OF THE NAVY
}

In the course of collecting Iowa historical and biographical material we often meet with rare and unusual things. A letter to Lieutenant (retired) Charles A. Clarke brought a most interesting response. Charles Ansyl Clarke was appointed from Fairfield, Iowa, as a cadet in the Naval Academy at Annapolis in July, 1864 , and was graduated June 4, 1869. He was promoted to ensign July 12, 1870, to master March 22, 1873, and to lieutenant July 11, 1877. He had an active life as an officer until September 15, 1897, when he was retired. He is still living happily at his home at La Jolla, California, while his friend, Rear Admiral Fletcher, resides at Washington, D. C. The letter is self-explanatory.-Editor.

My dear Mr. Harlan:

La Jolla, Cal., Sept. 29, 1914.

My long delay in replying to your very excellent letter seems like an act of conspicuous discourtesy, but I assure you that such is not the case, and to convince you of this fact $\mathrm{I}$ am constrained to enter into a somewhat lengthy explanation, and of course, of a personal nature and of little interest.

Previous to retirement my duties in the naval service led me into all parts of the habitable world, and to many places uninhabitable. In the restricted quarters of my staterooms on board ship, it was impossible to take more than a few of my personal possessions, so having no home of my own in those days, I left chests and trunks scattered around at the different navy yards on the Atlantic and Pacific coasts where my ships fitted out. I also left many things at my mother's home in Fairfield, including two boxes of letters and papers, many of these latter of considerable importance. Sincê the receipt of your letter $I$ have been in correspondence with my sister, Emma W. Clarke of Faireld, and she informs me that all of the letters and papers (documents) were stolen from the barn in which the boxes were stored.

In the twelve years that we have had a home of our own in this village, we have been away ten summers, and the house has been occupied by comparative strangers. Upon the receipt of your letter I began the search for the documents I wished to send you, and which you so courteously expressed a wish to have, but up to this time my search has been without results, and I say this with very sincere regrets.

One of the papers I wished to send you was of very great historical importance, as it was the first official letter ever received by any government from the "Hermit Nation," Corea. I use this term because at that 
time (1872) Corea was a vassal of China, paid tribute to that country and was allowed no intercourse whatever with any other country. The way I came into possession of this letter is somewhat curious, and may be of passing interest to you, and I trust you will pardon me for giving some details.

In 1872 our fleet, the Asiatic, went to Chemulpo, Corea, (afterward noted in the war between Russia and Japan) nominally to enquirc into the murder of the officers and crew of a United States merchant ship, the General Sherman, but with the real purpose, I beiieve, of endeavoring to open up the country to civilization. We had on board our flagship, the Colorado, the United States minister to China, Mr. Low, and a staff of Chinese and other interpreters. Our ships anclsored off Chemulpo in the mouth of the Salee River, which leads up to the capital, Seoul. We spent several weeks surveying the waters in the vicinity. 'The natives showed the most determined opposition to our landing at any point-evidently in compliance with instructions from the government.

One day a man was seen coming down from the direction of Seoul. When abreast the ship he drove a stake into the ground, tied a large document to the top and then retired. As I was one of the Admiral's aids, he sent me ashore in his barge with an armed crew to get this letter. It was an official communication from the government, written . in the Corean chardacters, and translated, read, "Men, of what country are you? What is your object in coming here?" After I landed to get the letter, as a matter of precaution I ordered the boat's crew to shove off a short clistance from the shore, and to cover the hundreds of approaching natives with their guns. It did not take me long to get the letter and to return with "assumed" dignity to the boat. As I had taken some little risk the Admiral kindly allowed me to keep the original letter after the translation had been made. I afterward had a number of experiences of this sort, but some of them not so agreeable.

Later we took some boats up to survey the Salee River, and one of the forts fired on them, wounding some of our men. 'This was an act of war. Mr. Low's duties ended. The whole responsibility fell upon the Admiral, John Rodgers. We landed a battalion of over one thousand perfectly drilled men, fought continuously for two days and nights, captured six forts, killed and wounded over two thousand, and then returned to our seven ships. It was estimated that there were over ten thousand Coreans opposed to us, but the poor fellows had no modern arms, for that time, and I have always felt sorry for them, but it was our duty as a "civilized" nation to give them a lesson after they fired on our boats' flag. However, the whole thing was only an incident of a naval officer's career, and it has been long relegated to obscurity.

Now you see, Mr. Harlan, what you have led a garrulous old man into. My regret is that I did not look for the phpers before I told Sabin about them. 
Iowa has every reason to be very proud of one of her sons. I refer to Admiral Frank Friday Fletcher. Editorials in the great New York dailies mentioned his services in the highest terms, and President Wilson complimented him personally in the White House. I refer, of course, to Admiral Fletcher's exceptionally wise conduct of affairs at Vera Cruz. He has now received the greatest reward that can be given to any naval officer in times of peace, commander-in-chief of the North Atlantic fleet.

Sincerely yours, .

Charges A. Chanke. U. S. N.

\section{NEW STEAM MILL AT BLOOMINGTON (NOW MUSCATINE)}

Bennett's magnificent steam mill is now up and inclosed. It is 77 feet high in front and 67 in the rear. The chimney is 87 feet high and contains 90 thousand brick. The steam boilers are the finest we recollect ever having seen. Altogether it forms an imposing and splendid structure, built to stand for ages, we should think, and is an ornament to the town. The main building is 85 by 50 feet, and contains over 330,000 brick. 'The basement is of solid limestone masonry, with the foundation sunk eight fect below the ground floor. The mill is designed to manufacture 300 barrels of flour per day, consuming more than 1400 bushels of wheat daily.

This mill will prevent the shipment of wheat from this point, until it is manufactured into flour-a great saving to the country. This is one exemplification of the utility of this kind of improvement. The concern will employ, constantly, a large laboring force, and prevent the payment of freight upon the offal and save it to be consumed, in the town, and country around. The feed it will make for cows, pigs, horses and the like, will be of great. utility and usefulness to the citizens. Suecess attend the-enterprise.-The Bloomington Herald, Bloomington, Iowa, Saturday, November 18, 1848. (In the newspaper collection of the Historical, Memorial and Art Department.) 
Copyright of Annals of Iowa is the property of State of Iowa, by \& through the State Historical Society of Iowa and its content may not be copied or emailed to multiple sites or posted to a listserv without the copyright holder's express written permission. However, users may print, download, or email articles for individual use. 